\title{
Distribution patterns of Tetrapygus niger (Echinodermata: Echinoidea) off the central Chilean coast
}

\author{
Sebastián R. Rodríguez, F. Patricio Ojeda* \\ Departamento de Ecología, Facultad de Ciencias Biológicas, Pontificia Universidad Católica de Chile, Casilla 114-D, \\ Santiago, Chile
}

\begin{abstract}
We investigated spatial distribution and temporal occurrence patterns of Tetrapygus niger in the subtidal zone off the central Chilean coast from March to November 1990. The shallowest portion of the subtidal zone and the shallowest edge of the kelp forest of Lessonia trabeculata appeared to be important recruitment zones for this species. We found a significant number of recruits along the bed border, and a marked decrease of urchin abundance toward the center of the kelp. Data obtained in September and November outside the kelp bed showed juvenile urchins [i.e. $<24 \mathrm{~mm}$ test diameter (TDI] strongly associated with crevices. Size-frequency distributions at $2 \mathrm{~m}$ depth for those months also showed a large trough of intermediate-sized individuals (i.e. 15 to $30 \mathrm{~mm} \mathrm{TD}$ ). Temporal analysis of size-frequency distributions of individuals collected outside the kelp showed a relatively slow shift of modes between March and September and a major modal shift from September to November. Density values of urchins found in November were relatively low; however, the individuals appeared aggregated.
\end{abstract}

\section{INTRODUCTION}

Sea urchins are one of the most common components of near-shore marine ecosystem worldwide, often playing an important ecological role in shallow subtidal environments (Lawrence 1975, Harrold \& Pearse 1987). Tetrapygus niger (Molina, 1782) is a conspicuous arbacioid occurring along the temperate Pacific coast from northern Peru to the Strait of Magallanes (southern Chile), extending from the intertidal zone to $40 \mathrm{~m}$ depth (Larrain 1975). Despite this species being the most abundant species of sea urchin on the central Chilean coast, little quantitative information has been gathered on key aspects of its biology and ecology. In this paper we document basic information about spatial distribution and temporal occurrence patterns of a population from the central Chilean coast.

\footnotetext{
- Addressee for correspondence
}

\section{MATERIALS AND METHODS}

Sea urchins were collected at Punta de Tralca $\left(33^{\circ}\right.$ $35^{\prime} \mathrm{S}, 71^{\circ} 42^{\prime} \mathrm{W}$ ) off the central Chilean coast. The substrate of the subtidal zone at this site consists of sloping bedrock with large rocks and boulders in the shallowest portion ( 0 to $6 \mathrm{~m}$ depth) and an increasing proportion of sand at greater depth ( 6 to $18 \mathrm{~m}$ ). An extensive kelp bed of the brown macroalga Lessonia trabeculata occurs in this deeper area.

Sea urchins were sampled inside and outside the kelp forest using SCUBA from March 1990 to November 1990 . Outside the kelp, samples were taken during March, June, September and November. In each of these samples, 3 transects were carried out perpendicular to the shore. Three $0.25 \mathrm{~m}^{2}$ quadrat samples (Pringle 1984) were taken from each of 3 different depth ranges ( 1 to $2.5,3$ to 4 , and 5 to $6 \mathrm{~m}_{i}$ hereafter designated 2,4 and $6 \mathrm{~m}$ respectively) according to a stratified sampling design (Elliott 1977). All sea urchins 
found within each quadrat were collected, placed in labelled plastic bags and fixed in a 5 to $10 \%$ solution of buffered formalin-seawater mixture. In the laboratory, the sea urchins were counted and their test diameters (TD) measured with a caliper to the nearest $0.1 \mathrm{~mm}$. The gonads of individuals collected in June and September were removed, blotted on a paper towel, and weighed to the nearest $0.1 \mathrm{~g}$ (wet wt). Gonad indices (GI) were computed as wet gonad mass/wet body mass $\times 100$ for individuals of 2 different size classes (i.e. 30 to $40 \mathrm{~mm}$ TD and 40 to $50 \mathrm{~mm}$ TD). Statistical analyses were done on angular transformed data. Mean values of TD and GI were compared using 1-way ANOVAS followed by Student-Newman-Keuls (SNK) multiple comparisons tests (Sokal \& Rohlf 1981).

During September and November all small sea urchins found in crevices outside the kelp forest were collected along a bathymetric transect. Individuals were taken with forceps and deposited in sampling bags of 1 to $2 \mathrm{~mm}$ mesh size, counted and measured as described above. Likewise during November, 18 quadrats per depth were haphazardly taken from 2,4 and $6 \mathrm{~m}$ respectively. Abundance and spatial distributional patterns of sea urchins were computed. In order to establish the spatial distributional patterns of Tetrapygus niger during this month. Morisita's index of dispersion $\left(I_{\delta}\right)$ was used. This is a good comparative index when each sample contains the same number of sampling units (Elliot 1977).

During September, 3 additional transects were carried out perpendicular to the shore inside the kelp bed Three quadrat samples $\left(0.25 \mathrm{~m}^{2}\right)$ were taken between holdfasts from each of 3 depth ranges ( 6 to 7,8 to 9 , and 10 to $11 \mathrm{~m}_{\mathrm{i}}$ hereafter 7,9 and $11 \mathrm{~m}$ respectively). Addi-
$2 \mathrm{~m} \mathrm{DE}$ एTH

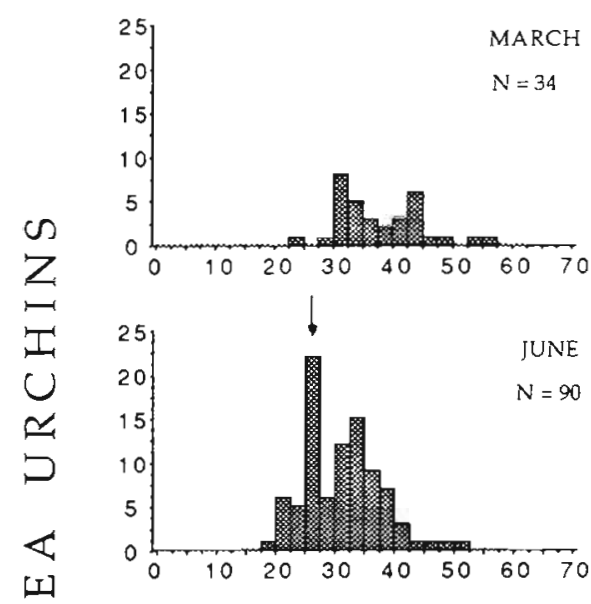

ก

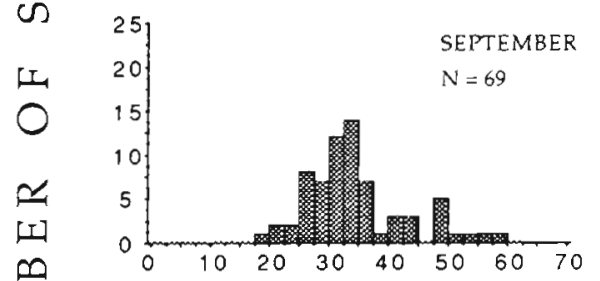

$\sum$

z

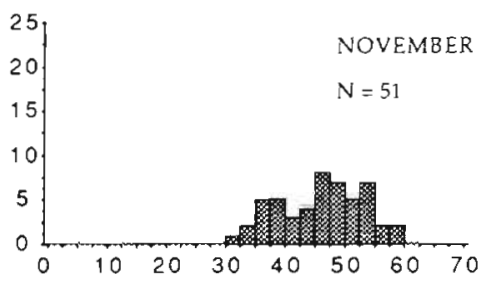

$4 \mathrm{~m} \mathrm{DEPTH}$
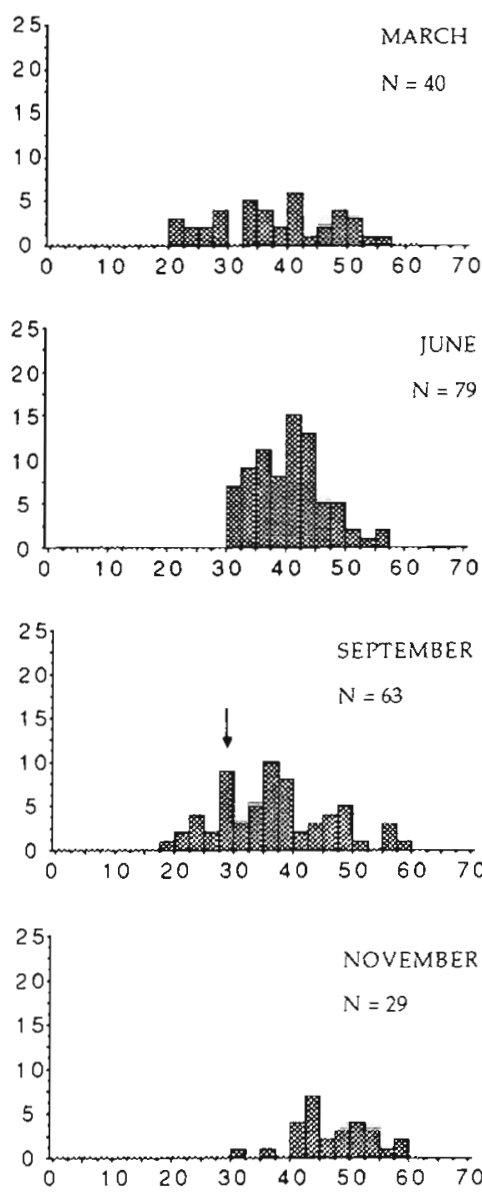

$6 \mathrm{~m}$ DEPTH
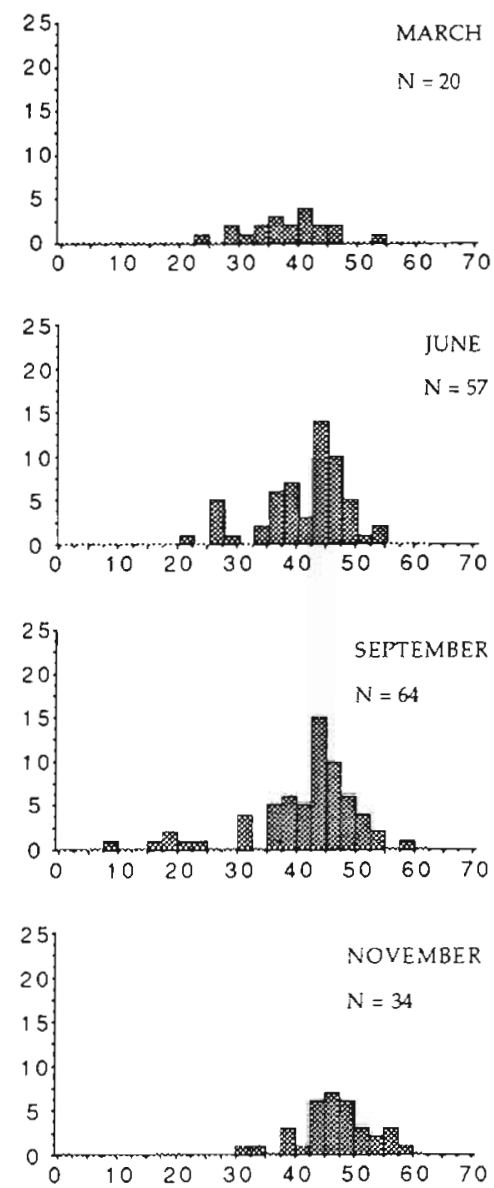

\section{TEST DIAMETER (m m)}

Fig. 1. Tetrapygus niger. Size-frequency distributions at different water depths and months collected outside the kelp bed at Punta de Tralca, Chile. Arrows indicate recruitment events which occurred at 2 and 4 m depth in June and September 1990 respectively 
tional samples of sea urchins inhabiting holdfasts and stipes of Lessonia trabeculata (between 6 and $7 \mathrm{~m}$ depth) were taken. These individuals were counted and measured as described above.

\section{RESULTS}

Size-frequency distributions of sea urchins found outside the kelp showed major recruitment events of $<30 \mathrm{~mm}$ TD individuals at 2 and $4 \mathrm{~m}$ in June and September respectively (Fig. 1).

Small individuals $(<24 \mathrm{~mm}$ TD) were rare $(5.6 \%$ of all sea urchins sampled). Individuals of $<24 \mathrm{~mm}$ TD were considered as juveniles since they did not have gonads. A large number of juveniles ( $70 \%$ of the total) were found in the crevices during September and November. All sea urchins in crevices were found at depths $<2.5 \mathrm{~m}$. Along the bathymetric gradient including all microhabitats outside the kelp bed, juveniles were mainly found at $2 \mathrm{~m}$ rather than at 4 and at $6 \mathrm{~m}$ ( $79 \%$ versus 10.5 and $10.5 \%$ respectively). Of the 356 individuals sampled in September, $98(27.5 \%)$ were juveniles. Of these juveniles, $57(58.2 \%)$ were found inside the kelp bed (16 on holdfasts of Lessonia trabeculata and 41 between plants), whereas 41 (41.8\%) were found outside the kelp. Twenty-four $(58.5 \%)$

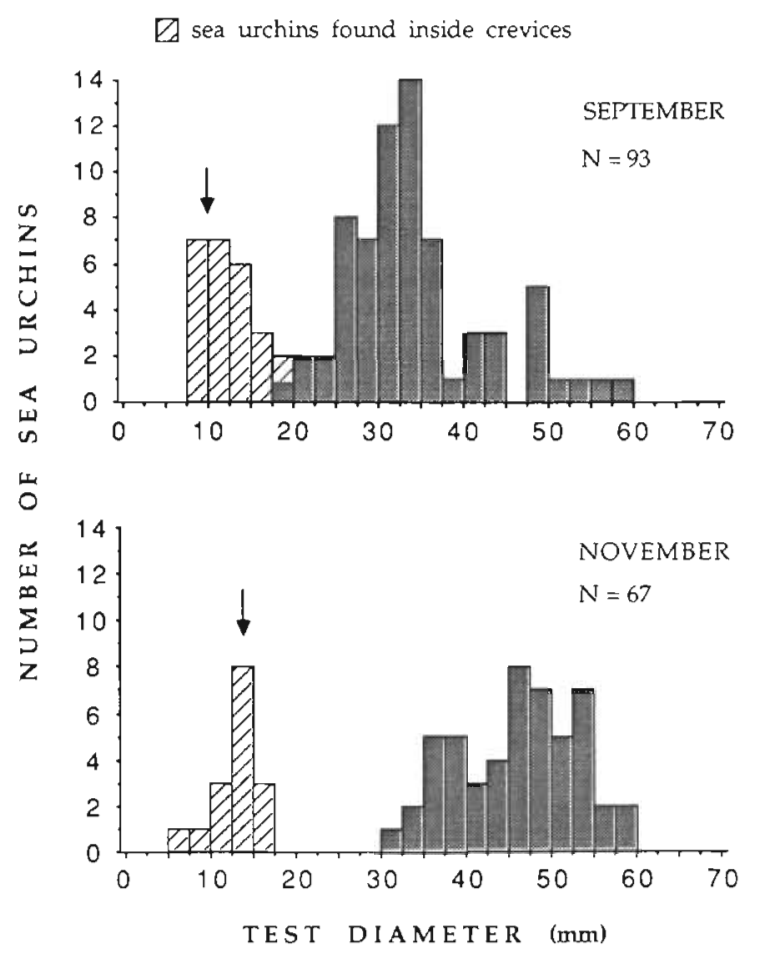

Fig. 2. Tetrapygus niger. Size-frequency distributions at $2 \mathrm{~m}$ depth collected in September and November 1990 outside the kelp bed at Punta de Tralca

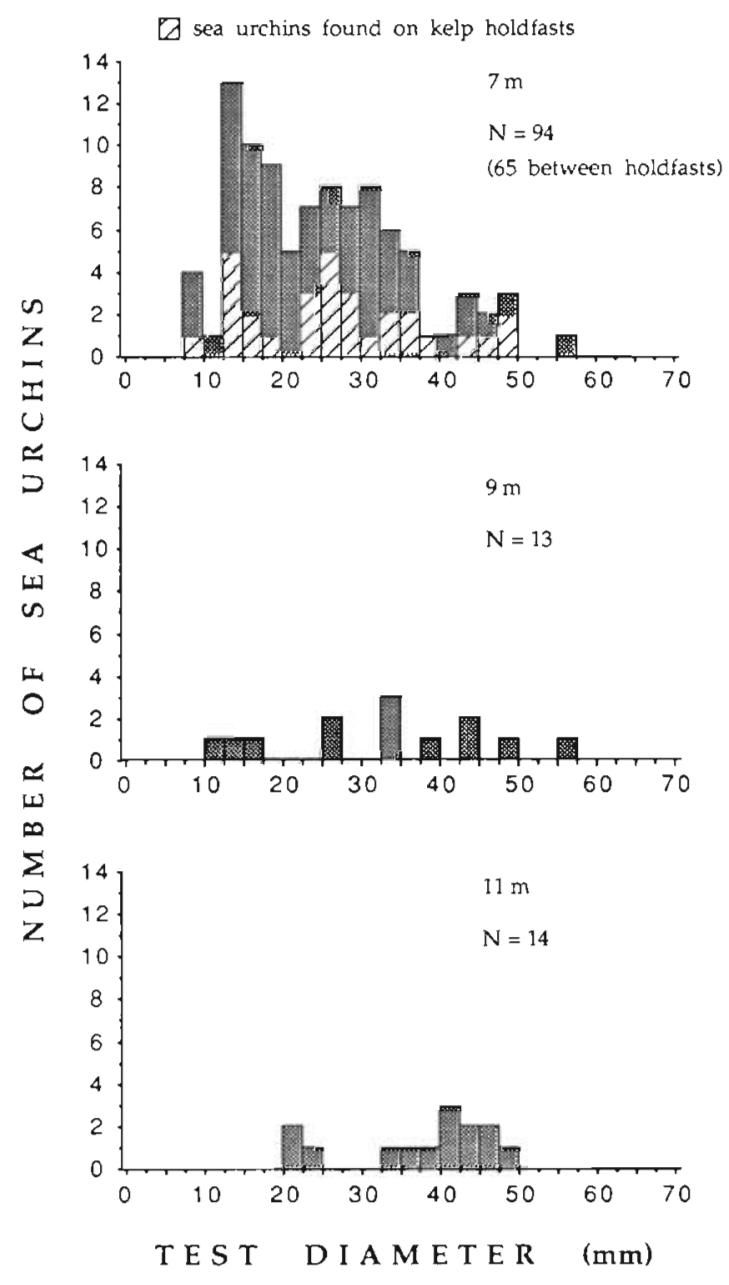

Fig. 3. Tetrapygus niger. Size-frequency distributions at different water depths collected in September 1990 inside the kelp bed at Punta de Tralca

juveniles sampled outside the kelp bed in September were found in crevices. In November, all juveniles were found in crevices. On the other hand, 36 of the 41 juveniles $(88 \%$ ) sampled between plants inside the kelp in September were found at the shallowest edge of the kelp $(7 \mathrm{~m})$.

The analysis of size-frequency distributions of all sea urchins sampled at $2 \mathrm{~m}$ depth in September and November outside the kelp bed, including juveniles in crevices, showed a new mode between 7 and $12 \mathrm{~mm}$ TD in September, and between 12 and $15 \mathrm{~mm}$ TD in November (Fig. 2). A large gap separated these small sea urchins from the large ones (15 and $25 \mathrm{~mm}$ TD in September, and 17 and $30 \mathrm{~mm}$ TD in November ).

Inside the kelp bed, 92 individuals were sampled between holdfasts in September along the bathymetric gradient. Of these, $65(69.2 \%)$ were found at the shallowest edge of the kelp ( $7 \mathrm{~m}$ depth), of which $55.4 \%$ were juveniles (Fig. 3). The number of individuals as 

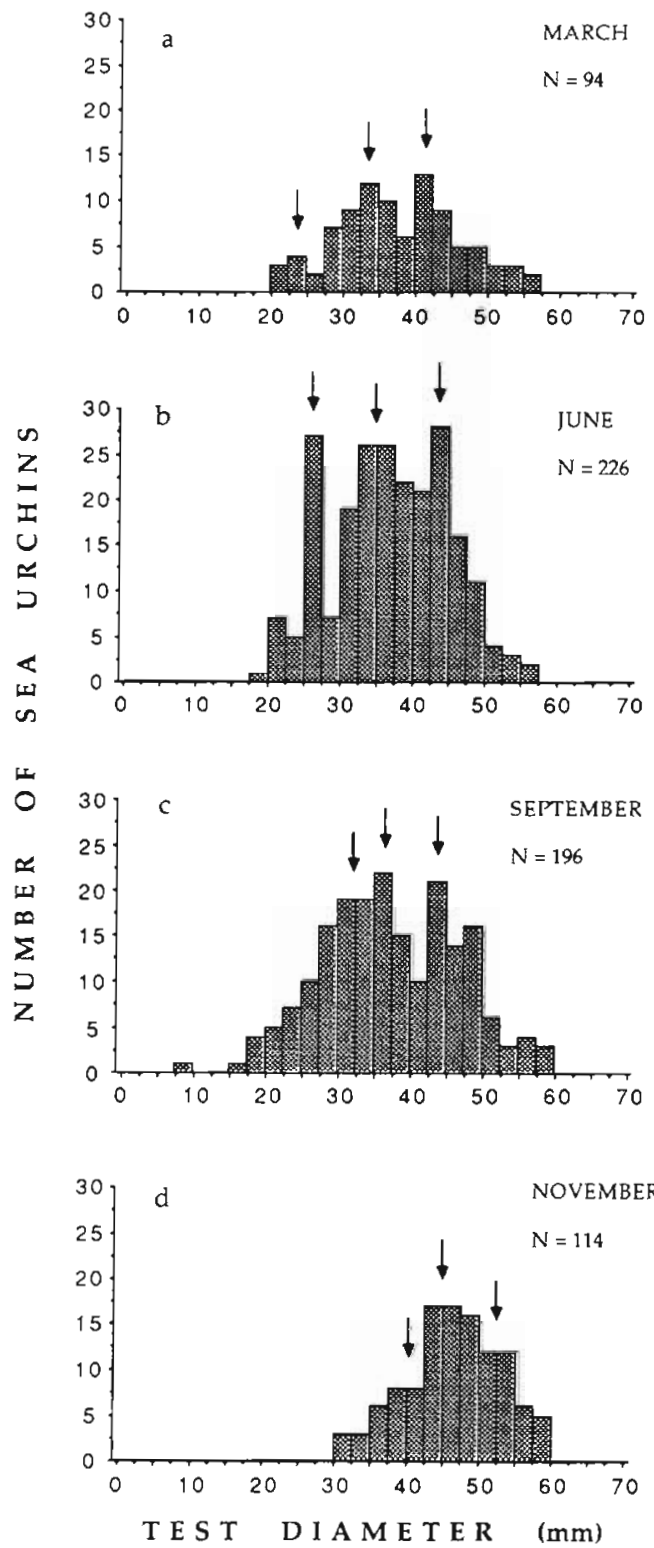

Fig. 4. Tetrapygus niger. Size-frequency distributions of all sea urchins at all depths collected in March, June, September and November 1990 outside the kelp bed. Modes indicated by arrows

well as the percentage of juveniles clearly decreased together with depth (Fig. 3).

A temporal analysis of size-frequency distributions of all sea urchins at all depths outside the kelp bed showed the presence of 3 modes in March: between 22 and 25, between 32 and 35, and between 40 and $45 \mathrm{~mm}$ TD (Fig. 4a). These modes shifted slightly in June. The first mode was particularly conspicuous as a result of recruitment during this month (Fig. 4b). Between June and September a major shift occurred in the $25 \mathrm{~mm}$ TD mode, appearing very close to the sec- ond mode (Fig. 4c). During this period, both the second and third modes remained almost stationary (Fig. 4c). In November, however, the size distribution was highly skewed towards small sizes (Fig. 4d).

No significant differences in gonad indices were detected between sea urchins collected in June and September outside the kelp bed, with the exception of males from 30 to $40 \mathrm{~mm}$ TD, which had significantly lower mean values $( \pm S E$ ) in September than in June ( $\mathrm{GI}=2.28 \pm 0.28$ and $3.79 \pm 0.26$ respectively; 1 -way ANOVA, $\mathrm{p}<0.001$, and a posteriori SNK test). Females from 40 to $50 \mathrm{~mm}$ TD collected inside the kelp bed in September had significantly higher mean gonad indices than those sampled outside the bed (GI $=5.96$ \pm 0.91 and $4.22 \pm 0.39$ respectively; 1 -way ANOVA, $\mathrm{p}=0.05$, and a posteriori SNK test).

Density estimates based on 54 quadrats haphazardly sampled outside the kelp bed in November showed values of $10.9,16.2$ and 15.3 ind. $\mathrm{m}^{-2}$ at 2,4 and $6 \mathrm{~m}$ depth respectively, and an aggregated spatial distribution pattern $\left(\mathrm{I}_{\delta}=1.65,3.06\right.$ and 2.16 at 2,4 and $6 \mathrm{~m}$ depth respectively; $\mathrm{p}<0.001$ ).

\section{DISCUSSION}

The ocurrence of a large number of small-sized individuals of Tetrapygus niger at $2 \mathrm{~m}$ depth in June and the presence of the most juveniles in crevices and cracks at depths less than $2.5 \mathrm{~m}$ in September and November indicate that the shallower portions of the subtidal zone, and probably the lower intertidal zone as well, are important nursery areas for this species on the central Chilean coast. Cancino \& Santelices (1984) documented a larval settlement pattern of a large suite of species, including Tetrapygus niger, in holdfasts of the kelp Lessonia nigrescens, which form a dense belt delimiting the lower intertidal zone of the central coast (Ojeda \& Santelices 1984). Recruitment of $T$. niger in holdfasts of $L$. nigrescens occurs mainly during summer (Vásquez \& Santelices 1984).

The shallowest edge of the bed of Lessonia trabeculata (i.e. $7 \mathrm{~m}$ depth) constitutes another important recruitment zone of Tetrapygus niger. Both juvenile and adult sea urchins greatly decreased in number with increasing depths. This differential pattern in abundance between habitats dominated by kelp and those devoid of macroalgae has been described for numerous sea urchin species from different geographic regions, such as in Strongylocentrotus purpuratus and $S$. franciscanus (Pearse et al. 1970), $S$. droebachiensis (Lang \& Mann 1976), and Evechinus chloroticus (Andrew \& Choat 1985). Several hypotheses have been suggested to explain such a recurrent distributional pattern, among them predation upon 
larvae by filter-feeders inhabiting kelp fronds (Pearse et al. 1970), predation by planktivorous fishes, tendency for larvae to settle soon after they receive appropriate cues upon entering the kelp (Tegner \& Dayton 1981), and post-settlement processes (e.g. differential mortality) (Rowley 1989).

Outside the kelp bed, juvenile Tetrapygus niger used crevices as microhabitat. Recruits of this species also occur under the spine canopy of adult Loxechinus albus, a sympatric but less common sea urchin species along this coast (unpubl. obs.). A similar phenomenon has been reported for juvenile Strongylocentrotus droebachiensis and S. purpuratus, which obtain protection under adult $S$. franciscanus (Duggins 1981). The presence of juveniles associated with topographic irregularities such as crevices, depressions and interstices of rocks and cobble, and their association with adult spine canopies (sensu Tegner \& Dayton 1977), have been largely related with a behavioral defense mechanism against predation (Andrew \& Choat 1982, Tegner \& Levin 1983, Breen et al. 1985, Ojeda \& Dearborn 1991, Scheibling \& Hamm 1991). Three alternative but non-exclusive hypotheses have been advanced to account for the above peculiar but widely observed pattern of juvenile distribution of sea urchins: (1) substrate selection by larvae, (2) differential mortality of metamorphosed larvae or juveniles on distinct microhabitats, and (3) secondary migration by juveniles (see Cameron \& Schroeter 1980, Rowley 1989)

It is possible that an ontogenetic shift in behavior of juvenile Tetrapygus niger from being cryptic (hiding in crevices) to being more exposed may contribute to the large trough in the size-frequency distribution observed in September and November. This ontogenetic shift may occur in sea urchins of about $15 \mathrm{~mm}$ TD, being the juveniles most exposed to fish predators (e.g. Graus nigra, which is the most important predator of this species; see Moreno 1972, Fuentes 1982). Similar explanations have been suggested for other sea urchin species which exhibit analogous distributional patterns (Andrew \& MacDiarmid 1991, Scheibling \& Hamm 1991). High predation rates on intermediatesized sea urchins and the formation of stationary modes composed of several year classes explaining bimodal size distributions have been proposed as alternative but non-exclusive hypotheses for a number of species (see Tegner \& Dayton 1981, Andrew \& Choat 1982, Himmelman et al. 1983, Tegner \& Levin 1983. Himmelman 1986, Ojeda \& Dearborn 1991).

Temporal analysis of size-frequency distribution of individuals collected outside the kelp forest showed a relatively slow shift of modes between March and September, especially between June and September, with the exception of the $25 \mathrm{~mm}$ TD mode. The slow shift observed for individuals larger than $30 \mathrm{~mm}$ TD during this period could be due, in part, to energy allocation to reproduction since Tetrapygus niger reaches its maximum gonad maturity by the end of the winter, with main spawning events in spring (Zamora 1989). The major modal shifts observed from September to November could be due to a somatic growth following the spawning season. Benthic algae, which represent an important food resource for $T$. niger (Contreras \& Castilla 1987), have their greatest growth during spring (Ojeda \& Santelices 1984).

Our study provides novel data related to basic biology and ecology aspects of this common sea urchin off the central Chilean coast. Further studies are necesary to understand the processes determining the recruitment and distribution patterns described in this work.

Acknowledgements. We thank G. Benavides, J. M. Farina, A. Palma and E. Varas for their important field assistance. We also acknowledge Dr J. Lawrence and 2 anonymous reviewers for suggestions and critical reading of an earlier draft of this manuscript. This research was funded by FONDECYT Grant 0753-91 to F.P.O. S. R. Rodríguez is presently Becario Residente en Investigación (DIUC) at the Depto Biología Celular y Molecular.

\section{LITERATURE CITED}

Andrew, N. L., Choat, J.H. (1982). The influence of predation and conspecific adults on the abundance of juvenile Evechinus chloroticus (Echinoidea: Echinometridae). Oecologia 54: 80-87

Andrew, N. L., Choat, J. H. (1985). Habitat related differences in the survivorship and growth of juvenile sea urchins. Mar. Ecol. Prog. Ser. 27: 155-161

Andrew, N. L., MacDiarmid, A. B. (1991). Interrelations between sea urchins and spiny lobsters in Northeastern New Zealand. Mar. Ecol, Prog. Ser 70: 211-222

Breen, P. A.. Carolsfeld, W., Yamanaka, K. L. (1985). Social behaviour of juvenile red sea urchins, Strongylocentrotus franciscanus (Agassiz). J. exp. mar. Biol. Ecol. 92: 45-61

Cameron, R. A., Schroeter, S. C. (1980). Sea urchin recruitment: effect of substrate selection on juvenile distribution. Mar. Ecol. Prog. Ser. 2: 243-247

Cancino, J., Santelices, B. (1984). Importancia ecólogica de los discos adhesivos de Lessonia nigrescens Bory (Phaeophyta) en Chile central. Revta chil. Hist. nat. 57: 23-33

Contreras, S., Castilla, J. C. (1987). Feeding behavior and morphological adaptations in two sympatric sea urchin species in central Chile. Mar. Ecol. Prog. Ser. 38: 217-224

Duggins, D. O. (1981). Interspecific facilitation in a guild of benthic marine herbivores. Oecologia 48: 157-163

Elliott, J. M. (1977). Some methods for the statistical analysis of samples of benthic invertebrates, 2 nd edn. Scient. Publs Freshwat. Biol. Ass. 25

Fuentes, H. R. (1982). Feeding habits of Graus nigra (Labridae) in coastal waters of Iquique in northern Chile. Jap. J. Ichthyol. 29: 95-98

Harrold, C., Pearse, J. S. (1987). The ecological role of echinoderms in kelp forests. Echinoderm. Studies 2: 137-233 
Himmelman, J. H. (1986). Population biology of green sea urchins on rocky barrens. Mar. Ecol. Prog. Ser. 33: 295-306

Himmelman, J. H., Cardinal, A., Bourget, E. (1983) Community development following removal of sea urchins, Strongylocentrotus droebachiensis, from the rocky subtidal zone of the St. Lawrence Estuary, eastern Canada, Oecologia 59: 27-39

Lang, C., Mann, K. H. (1976). Changes in sea urchin populations after the destruction of kelp beds. Mar. Biol. 36: 321-326

Larrain, A. P. (1975). Los echinoideos regulares fósiles y recientes de Chile. Gayana 35: 1-189

Lawrence, J. M. (1975). On the relationships between marine plants and sea urchins. Oceanogr. mar. Biol. A. Rev. 13: $213-286$

Moreno, C. A. (1972). Nicho alimentario de la 'Vieja negra' (Graus nigra Philippi). Not. mens. Mus. nac. Hist. nat. (Chile) 16:5-6

Ojeda, F. P., Dearborn, J. H. (1991). Feeding ecology of benthic mobile predators: experimental analyses of their influence in rocky subtidal communities of the Gulf of Maine. J. exp. mar. Biol. Ecol. 149: 13-44

Ojeda, F. P. Santelices, B. (1984). Ecological dominance of Lessonia nigrescens (Phaeophyta) in central Chile. Mar. Ecol. Prog. Ser. 19: 83-91

Pearse, J. S., Clark, M. E., Leighton, D. L., Mitchell, C. T., North, W. J. (1970). Marine waste disposal and sea urchin ecology. Ann. Rep., Kelp Habitat Improvement Project 1969-1970. California Inst. Tech., Pasadena

Pringle, J. D. (1984). Efficiency estimates for various quadrat sizes used in benthic sampling. Can. J. Fish. Aquat. Sci. 41: $1485-1489$

This article was presented by J. Lawrence, Tampa, Florida, USA
Rowley, R. J. (1989). Settlement and recruitment of sea urchins (Strongylocentrotus spp.) in a sea-urchin barren ground and a kelp bed: are populations regulated by settlement or post-settlement processes? Mar. Biol. 100: $485-494$

Scheibling, R. E., Hamm, J. (1991). Interactions between sea urchins (Strongylocentrotus droebachiensis) and their predators in field and laboratory experiments. Mar. Biol. 110: $105-116$

Sokal, R. R., Rohlf, F. J. (1981). Biometry, 2nd edn. W. H Freeman, San Francisco

Tegner, M. J., Dayton, P. K. (1977). Sea urchin recruitment patterns and implications of commercial fishing. Science 196: $324-326$

Tegner, M. J., Dayton, P. K. (1981). Population structure, recruitment and mortality of two sea urchins (Strongylocentrotus franciscanus and $S$. purpuratus) in a kelp forest. Mar. Ecol. Prog. Ser. 5: 255-268

Tegner, M. J., Levin, L. A. (1983). Spiny lobsters and sea urchins: analysis of a predator-prey interaction. J. exp. mar. Biol. Ecol. 73: 125-150

Vásquez, J. A., Santelices, B. (1984). Comunidades de macroinvertebrados en discos adhesivos de Lessonia nigrescens Bory (Phaeophyta) en Chile central. Revta chil. Hist. nat. 57: 131-154

Zamora, S. A. (1989). Comparaciones inter e intraespecificas en los ciclos reproductivos de Loxechinus albus (Molina, 1782) y Tetrapygus niger (Molina, 1782) (Echinodermata; Echinoidea) en dos localidades de la IV Región, Coquimbo, Chile. Thesis, Universidad Católica del Norte, Coquimbo

Manuscript first received: November 15, 1992 Revised version accepted: July 5, 1993 